\title{
Priorities to Policing a Smart City: A Search for Predilection of the Citizens
}

\author{
Arpita Mitra $^{1, ~ *, ~ N i r m a l ~ K a n t i ~ C h a k r a b a r t i ~}{ }^{2}$ \\ ${ }^{1}$ School of Law, Kalinga Institute of Industrial Technology (KIIT), Bhubaneswar, India \\ ${ }^{2}$ Department of Law, WB National University of Juridical Sciences, Kolkata, India \\ Email address: \\ arpitaamitra@gmail.com (A. Mitra),nkchakrabarti@gmail.com (N. K. Chakrabarti) \\ ${ }^{*}$ Corresponding author
}

To cite this article:

Arpita Mitra, Nirmal Kanti Chakrabarti. Priorities to Policing a Smart City: A Search for Predilection of the Citizens. International Journal of Law and Society. Vol. 4, No. 3, 2021, pp. 165-168. doi: 10.11648/j.ijls.20210403.12

Received: July 5, 2021; Accepted: July 16, 2021; Published: July 24, 2021

\begin{abstract}
The movement towards urban transformation has brought to light the need for modernization and technical sophistication of urban areas all across the globe. The smart cities have promised to serve the purpose of providing its residents the best amenities, infrastructure and security. In India too, the hundred smart cities are a part of the mission to transform urban areas through government and private enterprises and various developmental projects. In the process of this transition the law enforcement agencies are also witnessing a march towards technological advancements and better services to the stakeholders. In lieu of this, the present study is an attempt to unravel the opinion of the residents of two smart cities of Kolkata and Bhubaneswar setting priorities to the police commissionerates for initiating smart policing practices. Primary data has been collected through face to face interview of four hundred residents of two smart cities of eastern India namely Kolkata and Bhubaneswar. The residents have expressed their views about the priorities that the police in these cities should keep in mind while initiating best practices in smart policing. Further the findings have set forward a vision and goals that are to be given consideration to make the cities safer and secure for the residents. Technological upgradation to fight crimes, sustainable environments for the future generations and people friendly police can really fulfil the goals set forth.
\end{abstract}

Keywords: Community Policing, Smart City, Smart Policing

\section{Introduction}

A smart city attempts to provide to the residents an array of services to attract better living and a habitable ecosystem. Sustainability is the ultimate goal to be achieved through governance and public involvement. The opinion of the residents about the feel good ambience of makes it a success story. However as citizens they are the best to identify the challenges and priorities to policing a smart city. Each city has its unique culture, history and life style. The people are carrying forth the legacy of the smart city. While Kolkata has a colonial history and one of the metropolitan cities in India, Bhubaneswar is comparatively a new city with a smaller population and planned structure. The Smart City Mission envisions urban transformation and development in India. However, the initiatives undertaken will also make its implications in law enforcement. Today's police is expected to have close ties with the community and a simultaneous upgradation with respect to skills in technologies and risk management. The multiple tasks that the police has to shoulder in recent times makes their work stressful in keeping up with the expectations. Hence prioritising the multifarious activities would to some extent stream-line their job and ensure cooperation and involvement from the people. In this empirical study an effort has been made to explore the opinion of the residents about the priorities that the police should keep in consideration while initiating smart policing practices in the smart city of Kolkata and Bhubaneswar.

\section{Policing Smart Cities in India}

The Smart Cities Mission was initiated on 25 June, 2015. The primary aim of the Mission is to encourage cities that furnish basic infrastructure, speckless and sustainable geographical area and give a respectable quality of life to the citizens by providing 'smart solutions'. It intends to foster economic growth and ameliorate quality of life through all-encompassing efforts on 
social, economic, physical and organizational principles of the city. The concentration is on sustainable and inclusive improvement by creation of models to be replicated that will show the path as lighthouses to other cities aspiring to be a part of the same mission. A two stage competition has resulted in selection of 100 cities in India as smart cities. It is centrally sponsored scheme under the Union Ministry for Housing and Urban Affairs and the Union Government will give a financial aid up-to 48,000 crores in next five years with an average of 100 crores per city per year. An equal amount will be provided by the state, other additional resources are to be drawn through convergence Public Private Partnerships, grants form Finance Commission, ULB and Municipal Bonds. The six core principles that the Smart Cities are founded upon are (1) Community (2) More from less resources, (3) Innovation, Integration and Sustainability, (4) Convergence, (5) Technology and (6) Cooperative and Competitive Federalism. ${ }^{1}$

Policing is an organized form of order maintenance, peacekeeping, rule or law enforcement, crime investigation and prevention .... undertaken by individuals or organizations where such activities are viewed by them and or others as a key defining part of their purpose. [1] The functions of the police are (1) to protect society at large from violent individuals and (2) to protect the individual from violence at the hands of the many. [2] Police offficers are required with sophisticated surveillance technologies and having access to knowledge about a suspect may reduce their own certainty and thereby become empowered but when they reduce the suspects uncertainty the suspect becomes affected. A police officer can use communication technology to reduce doubtfulness about his own pedagogy of activity and thereby become authorised but the consequent decrease of subordinate police officers doubt will be experienced by the latter as disempowerment or loss of discretion. In risk society, policing is more than just a matter of repressive, correctional deterrent initiatives to control those who are unlawful. It is also a matter of surveillance of spreading awareness among population to ensure effective utilization. [3.4]

The functions of the police can be stream lined as follows: (1) representatives of criminal law, (2) preserving order, keeping peace, (3) assisting motorists, providing emergency medical help, (4) well-being of people in crisis, (5) general assistance and dissemination of information to the people. Police personnel spend a lot of their time doing duties which are not within the purview of society's opinion of police work. However today's police are rocked by several challenges: (a) bias and profiling police focus their attention on places and people who are thought to be associated with criminal behaviour; (b) use of force- it is a necessary right, but it generates controversy, mistrust, anger and ill will; (c) misconduct- police culture grants officers adequate chances of engaging in unlawful activities with very little scope of detection. Misdeeds may be favours, bribes, internal corruption, abuse of authority, excessive force and internal misconduct. [5]

\section{Research Foundation and Area Covered}

In this exploratory study, primary data has been collected

$1 \mathrm{https}: / /$ smartcities.gov.in/about-the-mission visited on 12th December, 2020) through face to face interview of the residents of Kolkata and Bhubaneswar. The sample size is of 400 hundred residents, 200 from each of the cities with an equal division of male and female. Non- probability convenience sampling has been used to collect the data. Secondary data has been collected through journal articles, books, web sources, etc.

Kolkata and Bhubaneswar is the area of the research. The Kolkata Police is functional with 9 divisions and 80 police stations (including 8 women police stations). It has the following units (a) Armed Police (b) Cyber crime Police station (c) Detective department (d) Central Division, (e) East Division (f) East Suburban Division (g) North and north Suburban Division (h) Port Division (i) South Division (j) South West Division (k) South East Division (l) South Suburban Division (m) Special Branch (n) Special Task Force (o) Enforcement Branch (p) Headquarters Force (q) Kolkata Police Directorate (r) Reserve Force (s) Security Control Organization (t) Traffic Police (u) Wireless Branch. The Kolkata Police has initiated several community policing programmes:

(A) Nabadisha (Night school for street children)

(B) Probaho (blood donation camp)

(C) Friendship Cup Football Tournament

(D) Kiran (computer training programme for under priviledged children)

(E) Pronam (Aid to senior citizens).

(F) Kolkata Goalz

(G) Sampark (Awareness drive for young residents)

(H) DIAL 100 to connect with senior police officials

(I)Jana Sanjog Sabha

(J) Sukanya ( self defense training programme)

(K)Helplines like Child Line Day/Night (1098), Control Room (100/1090), Medical 9830079999, Senior Citizen (9830088884), Traffic (1073/2000/2001), Women In Need (1091). ${ }^{2}$

The Police Commissionerate of Bhubaneswar and Cuttack was established under Section 4 of the Odisha Urban Police Act, 2003with effect from $1^{\text {st }}$ January, 2008. It has six special units namely: (a) Armed Police, (b) Courts of Executive Magistrates, (c) Mahila Police Stations register, investigate, enquire violence against women and children, (d) Energy Police Stations, (e) Training includes Urban Police and Traffic Training put under commssionerate since 2008 and (f) Red Cross. The commissionerate has also undertaken an array of community policing initiatives:

AMA police or Our Police has been launched in 2013. It provides three tier organizational structure: AMA Police Beat, AMA Police Samiti and District Advisory Committee, (b) Police Public Interface, (c) Special Police Officers, (d) Senior Citizen Security Cell, (e) Community Traffic System, (f) APOSSA YOJANA to promote SPORTS in Slums and Young and Juveniles against Narcotics Abuse, (g) Online registration of complaints/ E FIR for motor vehicle theft Cases. ${ }^{3}$

\footnotetext{
$2 \mathrm{http} / / /$ kolkatapolice.gov.in visited on $20^{\text {th }}$ March, 2021.

$3 \mathrm{http}: / /$ bhubaneswarcuttackpolice.gov.in visited on $23^{\text {rd }}$ March 2021.
} 


\section{In Search of a Theory}

The present research introspects the priorities as conceived by the people from the perspective of community policing which emphasizes the need for a collaborative police-public endeavour. Community policing proposes a dependence on a more people based transgression control that utilises the resources of the public as well as the police. [6] It is an innovative philosophy of policing which asks for police officers and citizens to work in tandem creatively to solve modern-day community problems related to crime, fear of crime, social and physical disorder and decline of neighbourhood sentiments. Police sets a fresh unison with the people allowing them greater scope of expression in setting local priorities and involving them in efforts to ameliorate the gross quality of life in their neighbourhoods. [7] Community policing is a multidimensional concept. According to Cordner, there are four dimensions of community policing: (a) philosophical dimension includes core ideas and beliefs about what the police should do; (b) strategic dimension encompasses two aspects -police officers spend less time in four wheelers by adopting alternative patrol strategies and each officer is assigned specific beats for extended periods; (c) tactical dimension includes problem solving whereby police officers are encouraged to investigate and develop an understanding towards local problems and strategise community specific solutions to address them; (d) organizational dimensions concerns altering traditional structural arrangements within police departments to support community policing activities.[8] [9] Community policing involves a enduring allegiance to the community including ordinary citizens by enhancing the mission of the police beyond crime control, providing full-service, personalized, and decentralized policing. It focuses on problem-solving through enhancement of obligations using both reactive and proactive policing while being operational within present facilities. This might include other dimensions of futuristic policing for example predictive policing for crime mapping and identifying crime hot spot. [10, 11] Thus community policing is more flexible, innovative, variant and appropriate to particular necessities while including programmes within its utilization, it is not a program in itself. $[12,13]$ It entails structural decentralization and a change of patrol, dedication to focused problem-oriented policing, accountability to the public and a loyalty to solve neighbourhood crime problems. $[14,15]$

\section{Priorities of Smart Policing}

Table 1. Priorities as identified by the people to make smart policing a reality.

\begin{tabular}{|c|c|c|c|c|c|}
\hline \multirow{2}{*}{ Priorities } & \multicolumn{2}{|c|}{ Scale 8 to 10 (Utmost Important) } & \multirow{2}{*}{ Priorities } & \multicolumn{2}{|c|}{ Scale 5 to 7 (Important) } \\
\hline & Kolkata & Bhubaneswar & & Kolkata & Bhubanewar \\
\hline Traffic Signalling & $95 \%$ & $78 \%$ & Identifying crime Hot Spots & $85 \%$ & $82 \%$ \\
\hline CCTV & $88 \%$ & $87 \%$ & Knowing the neighbourhood & $90 \%$ & $86 \%$ \\
\hline Prevention of crime & $75 \%$ & $70 \%$ & Community Service & $78 \%$ & $80 \%$ \\
\hline People's Empowerment & $73 \%$ & $65 \%$ & Awareness about recent legislsation & $71 \%$ & $76 \%$ \\
\hline Crime against animals & $71 \%$ & $68 \%$ & Protection of Public property & $87 \%$ & $90 \%$ \\
\hline Elder Abuse & $91 \%$ & $88 \%$ & Environmental crimes & $78 \%$ & $84 \%$ \\
\hline Violence against women & $97 \%$ & $92 \%$ & Road safety & $89 \%$ & $93 \%$ \\
\hline Police patrolling & $94 \%$ & $90 \%$ & Safety of public places & $85 \%$ & $82 \%$ \\
\hline Disaster Management & $91 \%$ & $97 \%$ & Awareness about traffic rules & $90 \%$ & $87 \%$ \\
\hline
\end{tabular}

The four hundred respondents were asked to mark out on a scale of 10 (10 being of utmost important) about twenty issues as per the priorities that they wish to set for the city police.

Most of the residents have marked out issues between a scale to 5 to 10 . In this table the issues have been categorised as utmost important (8 to 10) and important (5 to 7).

The priorities set forth by the residents of Kolkata Police tell us a lot about the trends in policing that the people are aware about. The rising cases of crime against women, children and elderly are a cause of concern for both the cities. Further up gradation of traffic to more tech-based system is also taken an issue to be addressed. Traffic congestion, road accidents and casualties thereof is a serious issue. Further empowerment of the people in policing the neighbourhood can prevent crime and check anomalies.

The people of both the cities are rocked by natural calamities and have witnessed quite a few super cyclones in the recent years. More proactive involvement of the police in disaster management is thus the call of the day. The issues which have been addressed as important and in between a scale of 5 to 7 are also quite serious ones. Combating environmental crime, checking pollution, road safety, identifying crime hot spots requires an efficient digitized system, greater technological expertise and know how. Digitization, computerization, tech-based administration are the priorities of smart cities all around the globe and same for India. The people are much more informed about the developments ans aspire the same for the smart city of which they are a part.

\section{The Future}

To sum it up, the findings indicate that the residents are quite aware of the recent developments in policing and its loopholes. The relationship between the police and the people is still not a comfortable one and carries the legacy of the colonial rule. The high density of population and the police 
public ratio is indicative of the distant police-public relationship in Kolkata. The awareness about community policing is more among the residents of Kolkata. This may be because community policing programmes were initiated about twenty ears back in Kolkata and it is a commissionerate which is more than 160 years old. Their is greater awareness and publicity about police initiatives among the people. Bhubaneswar and Cuttack commissionerate is relatively new and community policing initiatives are recent developments for which there may be lack of awareness among the people. The issues which have been prioritised as utmost important, points out the loopholes of the commissionerates. The national crime trends show an increasing crime rate with special reference to women, children, elderly and environment. This expose the weakness in crime prevention which is one of the foremost fucntions of policing. To improve on police public interaction more door to door patrolling is necessary. Accessibility of the police personnel can addresss several law and order problems. Moreover, enhanced use of surveillance technologies can help the police reach out to every nook and corner of the city and ensure prompt action and quick redressal.

The future of smart policing in India includes more proactive, developmental and innovative policies. The findings exposes the need for collaborative inclusive ventures. Taking the citizens into confidence by addressing their problems or a problem oriented approach can possibly help the police to tackle the challenges. Transparency in delivery of services, more information to the people and accountability for not being up to the mark can reduce stress and ensure a people friendly approach. Further, the use of new technologies which are eco-friendly and cost effective can foster greater utilization and effectiveness. The safety and security of the citizens is the primary concern of law enforcement and governance. Prioritising this can invariably reduce other challenges like violence against marginals, maintenance of law and order and environmental sustainability. Policy initiatives in this line can make Kolkata and Bhubaneswar smart cities in the truest sense.

\section{Acknowledgements}

A special thank to IMPRESS Indian Council of Social Science Research (ICSSR) for sponsoring the research project "Policing a Smart City: Priorities and Challenges towards Urban Transformation of Kolkata and Bhubaneswar".

\section{References}

[1] Jones, T and Newburn, T. 1998. Private Security and Public Policing. Oxford: Clarendon Press, pp. 18-19.

[2] Dillon, M. C. 1975. What are the Police for? in Viano, E. C. and Reiman J. H. (1975) (ed) The Police in Society. Toronto: Lexington, pp. 11-18.

[3] Ericson R. V. and Haggerty, K. D. 1997. Policing the Risk Society, Oxford: Clarendon, pp. 34-40.

[4] Ferret, J. \& Spenlehauer, V. 2009. Does Policing the risk society Hold the Road Risk? The British Journal of Criminology, 49 (2), pp. 150-64.

[5] Schafer, J. A. \& Bartollas C. 2008. The Police in Shoham, S. G. Beck $\mathrm{O}$, and Kent M. ed. International Handbook of Penology, Florida: CRC Press, pp. 443-478.

[6] Weisburd D \& Eck, J. E. 2004. What can Police do to reduce Crime, Disorder and Fear? The Annals of the American Academy of Political and Social Science, 59 (3), pp. 42-65.

[7] Carter, D. L. 1995. Politics and Community Policing Variables of Change the Political Environment. Public Administration Quarterly, 19 (1), pp. 6-25.

[8] Cordner, G. W 1999. Elements of Community Policing in Policing Perspectives: An Anthology ed. Gaines, L. K. and Cordner, G. W. Los Angeles: Roxbury.

[9] Reisig, M. D. 2010. Community and Problem Oriented Policing. Crime and Justice, 3 (1), pp. 1-53.

[10] Trojanowicz, R. \& Bucqueroux, B. 1990. Community Policing. A Contemporary Perspective. Cincinnati, $\mathrm{OH}$; Anderson Publishing Co.

[11] Roberg, R., Novak, K., Cordner, G.,\& Smith, B. 2015. Police and Society. $6^{\text {th }}$ Edition. New York: Oxford University Press.

[12] Ferrandino, J. 2013. "Community Policing: What it is not?" in Peak, K. J. (ed.), Encyclopedia of Community Policing and Problem Solving, Los Angeles: Sage, pp. 62-65.

[13] Meijer, A. \& Martijn, W. 2019. Predictive Policing: Review of Benefits and Drawbacks, International Journal of Public Administration, 42 (12), pp. 1031-39.

[14] Skogan W. G. and Harnett S. M. 1997. Community Policing: Chicago Style. New York: Oxford University Press, pp. 4-8.

[15] Greenberg, S. F. 2017. Frontline Policing in the $21^{\text {st }}$ Century: Mastery of Police Patrol. Cham, Switzerland: Palgrave Macmillan, pp. 413-431. 